Article

\title{
Blocking backward reaction on hydrogen evolution cocatalyst in a photosystem II hybrid Z-scheme water splitting system
}

\author{
Zhen Li a ${ }^{\text {a,b }}$, Yu Qi a, Wangyin Wang a, Deng Li a,b, Zheng Li a,b, Yanan Xiao b,c, Guangye Han c, \\ Jian-Ren Shen c,d, Can Li ${ }^{\text {a,* }}$ \\ a State Key Laboratory of Catalysis, Dalian Institute of Chemical Physics, Chinese Academy of Sciences, Dalian National Laboratory for Clean Energy, \\ Collaborative Innovation Center of Chemistry for Energy Materials (iChEM), Dalian 116023, Liaoning, China \\ b University of Chinese Academy of Sciences, Beijing 100049, China \\ c Photosynthesis Research Center, Key Laboratory of Photobiology, Institute of Botany, Chinese Academy of Sciences, Beijing 100093, China \\ d Research Institute for Interdisciplinary Science, Graduate School of Natural Science and Technology, Okayama University, Okayama 700-8530, Japan
}

\section{A R T I C L E I N F O}

\section{Article history:}

Received 21 November 2018

Accepted 7 January 2019

Published 5 April 2019

\section{Keywords:}

Water splitting

Cocatalyst

Backward reaction

Hydrogen oxidation

Photosystem II

\begin{abstract}
A B S T R A C T
Photocatalytic Z-scheme water splitting is considered as a promising approach to produce solar hydrogen. However, the forward hydrogen production reaction is often impeded by backward reactions. In the present study, in a photosystem II-integrated hybrid Z-scheme water splitting system, the backward hydrogen oxidation reaction was significantly suppressed by loading a $\mathrm{PtCrO}_{x} \mathrm{cocata}^{-}$ lyst on a $\mathrm{ZrO}_{2} / \mathrm{TaON}$ photocatalyst. Due to the weak chemisorption and activation of molecular hydrogen on $\mathrm{PtCrO}_{x}$, where $\mathrm{Pt}$ is stabilized in the oxidized forms, $\mathrm{Pt} \mathrm{tI}^{\mathrm{II}}$ and $\mathrm{Pt}{ }^{\mathrm{IV}}$, hydrogen oxidation is inhibited. However, it is remarkably well-catalyzed by the metallic Pt cocatalyst, thereby rapidly consuming the produced hydrogen. This work describes an approach to inhibit the backward reaction in the photosystem II-integrated hybrid Z-scheme water splitting system using $\mathrm{Fe}(\mathrm{CN})_{6}{ }^{3-} / \mathrm{Fe}(\mathrm{CN})_{6}{ }^{4-}$ redox couple as an electron shuttle.
\end{abstract}

(C) 2019, Dalian Institute of Chemical Physics, Chinese Academy of Sciences. Published by Elsevier B.V. All rights reserved.

\section{Introduction}

Z-scheme electron transfer mode in natural photosynthesis is well-known for combining two photosynthetic systems and separating the oxidation and reduction reactions spatially to avoid undesirable charge recombination [1-5]. Learning from nature's Z-scheme, the artificial Z-scheme solar water splitting system, combining two photocatalysts responsible for the independent oxygen evolution reaction (OER) and hydrogen evolution reaction (HER) through an electron transfer assisted by electron mediators, has been extensively studied for the solar hydrogen production [6-9]. As the redox potential of the shuttle mediator is located between the conduction band (CB) of the OER photocatalyst and the valance band (VB) of the HER photocatalyst, the forward electron transfer reaction is easily hindered by the redox reactions (so-called "backward reactions") of the shuttle mediators, resulting in a lower efficiency of the solar-to-hydrogen conversion [10-14]. Avoiding the backward reaction therefore becomes one of the crucial issues in constructing an efficient Z-scheme water splitting system. By

\footnotetext{
* Corresponding author. Tel: +86-411-84379070; Fax: +86-411-84694447; E-mail: canli@dicp.ac.cn

This work was supported by the Strategic Priority Research Program of Chinese Academy of Sciences (XDB17000000), the Key Research Program of Frontier Sciences, CAS (QYZDY-SSW-JSC023), the National Natural Science Foundation of China $(21603224,31470339)$, and the National Key R\&D Program of China (2017YFA0503700).

DOI: S1872-2067(19)63311-5 | http://www.sciencedirect.com/science/journal/18722067 | Chin. J. Catal., Vol. 40, No. 4, April 2019
} 
making channels for gas production and diffusion [10], constructing selective cocatalysts [11], and modifying the surface of photocatalyst [13], the backward reactions are inhibited to some extent; however, such approaches are still limited.

The redox couple $\mathrm{Fe}(\mathrm{CN})_{6}{ }^{4-/ 3-}$ is an efficient electron mediator frequently employed in photosystem II (PSII)-integrated biotic-abiotic hybrid Z-scheme water splitting systems, which have received much attention owing to the application of the excellent natural water oxidation enzyme (PSII) in solar energy conversion, and also for the research on the basic scientific issues in water splitting [15-17]. $\mathrm{Fe}(\mathrm{CN}) 6^{3-}$, as an efficient exogenous electron acceptor of PSII, is capable of extracting the photogenerated electrons from the reducing side of PSII during the light-driven water oxidation process without triggering any undesirable side reactions, and the produced $\mathrm{Fe}(\mathrm{CN}) 6^{4-}$ then transfers the electrons to the artificial component for water reduction. However, the backward reactions caused by the shuttle mediators have also been encountered in the $\mathrm{Fe}(\mathrm{CN})_{6}{ }^{4-/ 3-}-$ mediated biotic-abiotic hybrid systems. Even though the OER is almost unaffected owing to the highly selective active sites of PSII for water oxidation and $\mathrm{Fe}(\mathrm{CN}) 6^{3-}$ reduction [18-20], the inhibition of HER on the semiconductor photocatalyst happens easily, which limits the usability of the combination of PSII and artificial materials for solar water splitting.

In the present study, $\mathrm{ZrO}_{2} / \mathrm{TaON}$ was employed as the HER photocatalyst to construct a $\mathrm{PSII}-\mathrm{ZrO}_{2} / \mathrm{TaON}$ hybrid Z-scheme water splitting system, and $\mathrm{PtCrO}_{x}$ particles were loaded on $\mathrm{ZrO}_{2} / \mathrm{TaON}$ as HER cocatalysts. We found that the backward reaction of hydrogen oxidation by $\mathrm{Fe}(\mathrm{CN}) 6^{3-}$ can be catalyzed and accelerated remarkably on the metallic Pt cocatalyst; however, it was not catalyzed on the oxide $\mathrm{PtCrO}_{x}$ due to a weak adsorption and activation of $\mathrm{H}_{2}$. The higher oxidation states of $\mathrm{PtII}^{\mathrm{II}}$ and $\mathrm{Pt}^{\mathrm{IV}}$ in $\mathrm{PtCrO}_{x}$ were well-sustained during the HER, and might be stabilized by the coordination of the surrounding $\mathrm{CrO}_{x}$ species that protect $\mathrm{Pt}^{\mathrm{II}}$ and $\mathrm{Pt}^{\mathrm{IV}}$ from being reduced into metallic Pt even on aggregation of the photogenerated electrons. Therefore, a long-term hydrogen evolution took place on $\mathrm{PtCrO}_{x}$-loaded $\mathrm{ZrO}_{2} / \mathrm{TaON}$, with $\mathrm{Fe}(\mathrm{CN})_{6}{ }^{4-}$ as the electron donor. Finally, Z-scheme overall water splitting was achieved successfully through the $\mathrm{Fe}(\mathrm{CN})_{6}{ }^{3-/ 4-}$-assisted electron transfer from PSII to $\mathrm{PtCrO}_{x}$-loaded $\mathrm{ZrO}_{2} / \mathrm{TaON}$. This work paves a new way to inhibit the backward reaction caused by the electron mediator, $\mathrm{Fe}(\mathrm{CN}) 6^{3-/ 4-}$, for an efficient electron transfer between PSII and the artificial photocatalyst in the Z-scheme water splitting system.

\section{Experimental}

\subsection{Preparation of $\mathrm{ZrO}_{2} / \mathrm{TaON}$}

$\mathrm{ZrO}_{2} / \mathrm{TaON}$ was synthesized as reported previously [21]. Typically, $\mathrm{Ta}_{2} \mathrm{O}_{5}$ and $\mathrm{ZrO}\left(\mathrm{NO}_{3}\right)_{2}$ were mixed with a 0.1 molar ratio of $\mathrm{Zr} / \mathrm{Ta}$ in a small amount of methanol, dried at $70{ }^{\circ} \mathrm{C}$ for $1 \mathrm{~h}$, and subsequently heated in air at $800{ }^{\circ} \mathrm{C}$ for $2 \mathrm{~h}$ to yield a $\mathrm{ZrO}_{2} / \mathrm{Ta}_{2} \mathrm{O}_{5}$ composite. $\mathrm{ZrO}_{2} / \mathrm{TaON}$ was obtained by nitridation of the as-prepared $\mathrm{ZrO}_{2} / \mathrm{Ta}_{2} \mathrm{O}_{5}$ powder at $900{ }^{\circ} \mathrm{C}$ under a flow of $\mathrm{NH}_{3}\left(20 \mathrm{~mL} \mathrm{~min}^{-1}\right)$ for $20 \mathrm{~h}$.

\subsection{Photodeposition of cocatalysts}

Metallic Pt particles (1 wt \% Pt) and the mixed oxide, $\mathrm{PtCrO}_{x}$ (1 wt\% Pt, Cr: according to the different $\mathrm{Cr} / \mathrm{Pt}$ mass ratios), were loaded on the surface of $\mathrm{ZrO}_{2} / \mathrm{TaON}$ by photodeposition. $\mathrm{ZrO}_{2} / \mathrm{TaON}(0.2 \mathrm{~g}$ ) was dispersed in a $100 \mathrm{~mL}$ aqueous solution containing $20 \mathrm{vol} \%$ methanol as the electron donor, to which the calculated volume of concentrated $\left(\mathrm{NH}_{4}\right)_{2} \mathrm{PtCl}_{6}$ and $\mathrm{K}_{2} \mathrm{CrO}_{4}$ solution was added as precursors. The photodeposition process was carried out under the full-spectrum irradiation of a Xenon lamp for $6 \mathrm{~h}$ at $15{ }^{\circ} \mathrm{C}$ in a Pyrex-top irradiation type reaction vessel connected to a closed gas circulation system. After photodeposition, the resultant powder was washed with distilled water and dried overnight at $65^{\circ} \mathrm{C}$ in an oven.

\subsection{Preparation of electrodes}

$\mathrm{ZrO}_{2} / \mathrm{TaON} / \mathrm{FTO}$ electrodes were prepared by the electrophoresis method. $\mathrm{ZrO}_{2} / \mathrm{TaON}$ powder $(20 \mathrm{mg}$ ) was dispersed in $25 \mathrm{~mL}$ acetone containing $15 \mathrm{mg} \mathrm{I} \mathrm{I}_{2}$ under an ultrasonic treatment for $10 \mathrm{~min}$. FTO plates $(1 \mathrm{~cm} \times 2 \mathrm{~cm})$ were used as substrates after they were ultrasonically washed in acetone, isopropanol, ethanol, and water successively. Two FTO plates were connected to a two-electrode system with their conductive layers face to face, and the as-prepared $\mathrm{ZrO}_{2} / \mathrm{TaON} / \mathrm{I}_{2}$ solution was used as the electrolyte. A pulsing voltage of $20 \mathrm{~V}$ was applied 10 times, each time lasting for $10 \mathrm{~s}$ with an interval of $10 \mathrm{~s}$, upon which, $\mathrm{ZrO}_{2} / \mathrm{TaON}$ powder got deposited onto the FTO anode. The electrode was dried at $65{ }^{\circ} \mathrm{C}$ in an oven for $2 \mathrm{~h}$. The cocatalysts, $\mathrm{Pt}$ and $\mathrm{PtCrO}_{x}$, were then photo-deposited onto the $\mathrm{ZrO}_{2}$ /TaON/FTO surface. First, the $\mathrm{ZrO}_{2} / \mathrm{TaON} / \mathrm{FTO}$ plate was placed at the bottom of a beaker and $25 \mathrm{~mL}$ $\left(\mathrm{NH}_{4}\right)_{2} \mathrm{PtCl}_{6}$-methanol mixed aqueous solution, with the mass of the Pt element being $0.25 \mathrm{mg}$, or $25 \mathrm{~mL}$ $\left(\mathrm{NH}_{4}\right)_{2} \mathrm{PtCl}_{6} / \mathrm{K}_{2} \mathrm{CrO}_{4}$-methanol mixed aqueous solution, with the mass of the Pt and Cr elements being 0.25 and $0.125 \mathrm{mg}$, respectively, was added for the respective deposition of $\mathrm{Pt}$ or $\mathrm{PtCrO}_{x}$. The volume proportion of methanol in the mixed solutions is $20 \%$. Photodeposition was carried out under the light of a Xenon lamp $(\lambda \geq 420 \mathrm{~nm})$ for $4 \mathrm{~h}$ at $15^{\circ} \mathrm{C}$. The electrode was carefully washed with distilled water and then dried at 65 ${ }^{\circ} \mathrm{C}$ in an oven for $2 \mathrm{~h}$.

\subsection{Preparation of the PSII core complex}

PSII core complex was isolated from the thermophilic cyanobacterium T. vulcanus as described previously [22,23], and finally dispersed in an MES solution (30 mM MES, $20 \mathrm{mM} \mathrm{NaCl}$, $3 \mathrm{mM} \mathrm{CaCl}_{2}, \mathrm{pH}=6.0$ ). The concentration of Chl $a$ (denoted as [Chl $a]$ ) in the PSII sample was obtained according to the equation $[\mathrm{Chl} a]=\mathrm{A} 665 \times 13.4 \times$ dilution factor, in which A665 is the UV-Vis absorbance of the sample at $665 \mathrm{~nm}$ in methanol [24]. [Chl $a$ ] was employed for calculating the quantity of the PSII centers by using $35 \mathrm{Chl} a / \mathrm{PSII}$ [25]. Steady-state $\mathrm{O}_{2}$ evolution of the prepared PSII sample was measured with a Clark-type 
electrode at $30{ }^{\circ} \mathrm{C}$ with $0.5 \mathrm{mM}$ phenyl- $p$-benzoquinone and 0.5 $\mathrm{mM} \mathrm{K}_{3} \mathrm{Fe}(\mathrm{CN})_{6}$ as the electron acceptors, and the $\mathrm{O}_{2}$ evolution rate exceeded $3000 \mu \mathrm{mol} \mathrm{O}_{2}(\mathrm{mg} \text { of } \mathrm{Chl})^{-1} \mathrm{~h}^{-1}$ under a saturated illumination.

\subsection{Characterization of photocatalysts}

Morphologies of the cocatalysts were examined by high resolution transmission electron microscopy (HR-TEM, JEOL JEM-2000EX) and high-angle annular dark field scanning transmission electron microscopy (HAADF-STEM, JEM-ARM200F). Electronic states of the cocatalysts were examined by X-ray photoelectron spectroscopy (XPS) measurements on a VG ESCALAB MK2 spectroscope under a monochromatized $\mathrm{Al} \mathrm{K \alpha}$ excitation.

\subsection{Measurements of photocatalytic reactions and dark backward reactions}

For the photocatalytic half reactions and the overall water splitting reactions, a homemade airtight vessel with a top quartz window was utilized. Before irradiation, the vessel containing the reaction solution was connected to a vacuum/inert gas line to replace the air in the headspace with the Ar gas, and then placed in a thermostatic water bath with the temperature kept at $25{ }^{\circ} \mathrm{C}$ for the subsequent photocatalytic reaction. The gas produced during the reaction was monitored by injecting the headspace samples into a gas chromatography instrument (Agilent GC 7890, USA, 5A zeolite column and Ar carrier gas).

The dark backward reaction between hydrogen and $\mathrm{Fe}(\mathrm{CN})_{6}{ }^{3-}$ was carried out in the same homemade airtight vessel. For each reaction, either no photocatalyst or $40 \mathrm{mg}$ of it was dispersed in $20 \mathrm{~mL}$ of the PBS buffer $(\mathrm{pH}=6)$ containing 2 $\mathrm{mM} \mathrm{Fe}(\mathrm{CN})_{6}{ }^{3-}$. The vessel containing the reaction solution was filled with Ar gas and sealed when quantitative hydrogen gas was injected in for the backward reaction; however, it was not sealed when the reaction solution was bubbled with hydrogen gas.

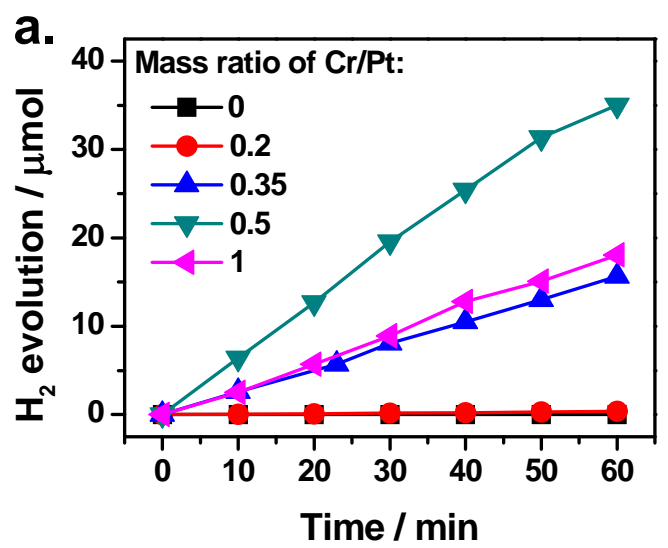

\subsection{Electrochemical measurements}

The electrochemical performances of the $\mathrm{ZrO}_{2} / \mathrm{TaON} / \mathrm{FTO}$ and the cocatalyst-loaded $\mathrm{ZrO}_{2} / \mathrm{TaON} / \mathrm{FTO}$ electrodes were measured in a three-electrode setup, where Pt electrode and the saturated calomel electrode (SCE) were employed as the counter and reference electrodes, respectively. The PBS buffer (100 mM phosphate, $15 \mathrm{mM} \mathrm{NaCl}, \mathrm{pH}=6$ ) containing $5 \mathrm{mM}$ $\mathrm{Fe}(\mathrm{CN}) 6^{3-}$ was used as the electrolyte. Linear sweep voltammetry (LSV) was carried out in the range of 0.2 to $-1.2 \mathrm{~V} \mathrm{vs.} \mathrm{SCE} \mathrm{at}$ a scan rate of $50 \mathrm{mV} \mathrm{s}^{-1}$ on a CHI 760D electrochemical workstation (Shanghai Chenhua Instruments, China). Electrochemical impedance spectroscopy (EIS) was carried out at the potential of $-0.2 \mathrm{~V}$ vs. SCE, with the AC potential frequency ranging from $0.1 \mathrm{~Hz}$ to $200 \mathrm{kHz}$ on a PARSTAT 2273 workstation (Princeton Applied Research).

\section{Results and discussion}

\subsection{Photocatalytic activities for hydrogen evolution}

$\mathrm{ZrO}_{2}$-modified $\mathrm{TaON}\left(\mathrm{ZrO}_{2} / \mathrm{TaON}\right)$, with the band gap of 2.5 $\mathrm{eV}$, has been previously demonstrated as a good photocatalyst for hydrogen production [26-28]. In the present study, $\mathrm{ZrO}_{2} / \mathrm{TaON}$ was employed to collaborate with the natural PSII core complex to construct a bio-artificial Z-scheme water splitting system. The redox mediator couple $\mathrm{Fe}(\mathrm{CN})_{6}{ }^{4-/ 3-}$ was used to transfer the electrons from PSII to the semiconductor photocatalyst. $\mathrm{Pt}$ and $\mathrm{PtCrO}_{x}$ particles with different $\mathrm{Cr} / \mathrm{Pt}$ mass ratios were loaded on $\mathrm{ZrO}_{2} / \mathrm{TaON}$ as cocatalysts through the photodeposition method described above. Fig. 1(a) depicts the time courses of hydrogen evolution on the cocatalyst-loaded $\mathrm{ZrO}_{2} / \mathrm{TaON}$ samples. Hydrogen evolution on the Pt-loaded sample was negligible, whereas the activities increased notably on the $\mathrm{PtCrO}_{x}$-loaded samples, reaching a maximum value at a $\mathrm{Cr} / \mathrm{Pt}$ ratio of 0.5 . Furthermore, the $\mathrm{PtCrO}_{x}(\mathrm{Cr} / \mathrm{Pt}=0.5)$-loaded sample was able to display a long-term hydrogen evolution for $9 \mathrm{~h}$ until the electron donor, $\mathrm{Fe}(\mathrm{CN})_{6}{ }^{4-}$, was consumed com-

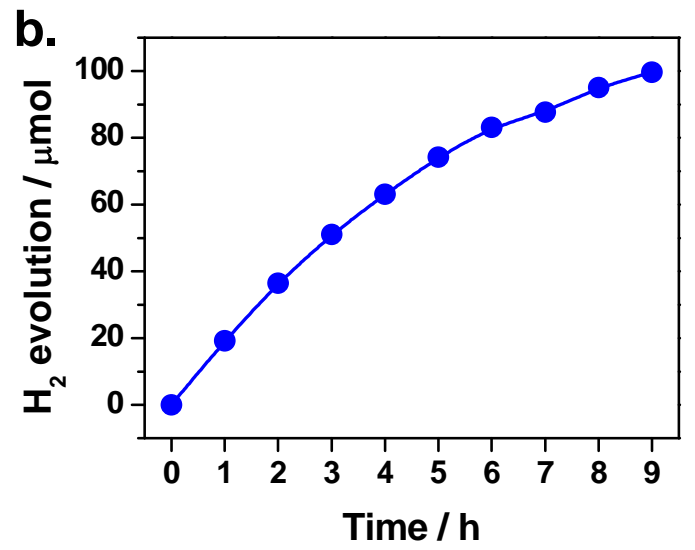

Fig. 1. Hydrogen evolution performances of cocatalyst-loaded $\mathrm{ZrO}_{2} / \mathrm{TaON}$. (a) Time course of hydrogen evolution on cocatalyst-loaded $\mathrm{ZrO} / 2$ TaON with different $\mathrm{Cr} / \mathrm{Pt}$ mass ratios; (b) Long-term hydrogen evolution on $\mathrm{PtCrO}_{x}(0.5)-\mathrm{ZrO}_{2} / \mathrm{TaON}$. For each reaction, 20 mg photocatalyst was dispersed in $20 \mathrm{~mL}$ PBS buffer $(\mathrm{pH}=6)$ containing $10 \mathrm{mM} \mathrm{Fe}(\mathrm{CN})_{6}{ }^{4-}$ as the electron donor. Light source: $300 \mathrm{~W}$ Xenon lamp $(\lambda \geq 420 \mathrm{~nm})$. 
pletely (Fig. 1(b)). As a control experiment, when only $\mathrm{CrO}_{x}$ was loaded on $\mathrm{ZrO}_{2} / \mathrm{TaON}$ without addition of the Pt precursor during photodeposition, no hydrogen was detected in the HER with $\mathrm{Fe}(\mathrm{CN})_{6}{ }^{4-}$ as the donor on this Pt-absent sample, which indicates that the Pt species in $\mathrm{PtCrO}_{x}$ is indispensable for hydrogen production.

\subsection{Composition and morphology of the cocatalysts}

To investigate the relationship between the photocatalytic activity and the composition and structure of the cocatalysts, the electronic states and morphologies of the $\mathrm{Pt}$ and $\mathrm{Cr}$ species on $\mathrm{ZrO}_{2} / \mathrm{TaON}$ were characterized by XPS and HR-TEM. Fig. 2(a) shows the XPS spectra of Pt $4 f$ of the as-prepared samples with different $\mathrm{Cr} / \mathrm{Pt}$ ratios. For the Pt-only loaded sample $(\mathrm{Cr} / \mathrm{Pt}=0)$, the spectrum is mainly attributed to the $\mathrm{Pt}^{0}$ species at the binding energies of ca. $70.2\left(4 f_{7 / 2}\right)$ and $73.6 \mathrm{eV}\left(4 f_{5 / 2}\right)$, and the small fitted peaks centered at ca. $72.3\left(4 f_{7 / 2}\right)$ and 75.7 $\mathrm{eV}\left(4 f_{5 / 2}\right)$ are attributed to the PtII species. With the addition of the $\mathrm{Cr}$ species, the XPS peaks due to $\mathrm{Pt}^{\mathrm{II}}$ and $\mathrm{Pt}{ }^{\mathrm{IV}}$ (ca. $74.5 \mathrm{eV}$ for $4 f_{7 / 2}, 77.9 \mathrm{eV}$ for $4 f_{5 / 2}$ ) became dominant, whereas those due to $\mathrm{Pt}^{0}$ decreased remarkably. There is a gradual change in the spectra with the increasing $\mathrm{Cr} / \mathrm{Pt}$ ratio; the $\mathrm{Pt}^{0}$ peaks at the low binding energy disappear, whereas the $\mathrm{Pt}^{\mathrm{IV}}$ peaks at the higher binding energy grow up, until reaching a stable proportion of $\mathrm{Pt}^{\mathrm{II}}$ and $\mathrm{Pt}^{\mathrm{IV}}$ after the $\mathrm{Cr} / \mathrm{Pt}$ ratio is higher than 0.5. The $\mathrm{Cr} 2 p$ spectra in all of the $\mathrm{PtCrO}_{x}$-loaded samples show the same peaks at the binding energies of ca. 576.5 and $586.4 \mathrm{eV}$, corresponding to the $2 p_{3 / 2}$ and $2 p_{1 / 2}$ electrons, respectively, of the $\mathrm{Cr}_{2} \mathrm{O}_{3}$ species (Fig. S1). Accordingly, it could be speculated that the chemical state of Pt was regulated by the $\mathrm{CrO}_{x}$ species during the photodeposition process, and the HER activity of $\mathrm{PtCrO}_{x}-\mathrm{ZrO}_{2} / \mathrm{TaON}$ is sensitive to the chemical state of $\mathrm{Pt}$.

XPS spectra after the HER with $\mathrm{Fe}(\mathrm{CN})_{6}{ }^{4-}$ as the electron donor were also recorded. For $\mathrm{Pt}-\mathrm{ZrO}_{2} / \mathrm{TaON}$, the proportion of
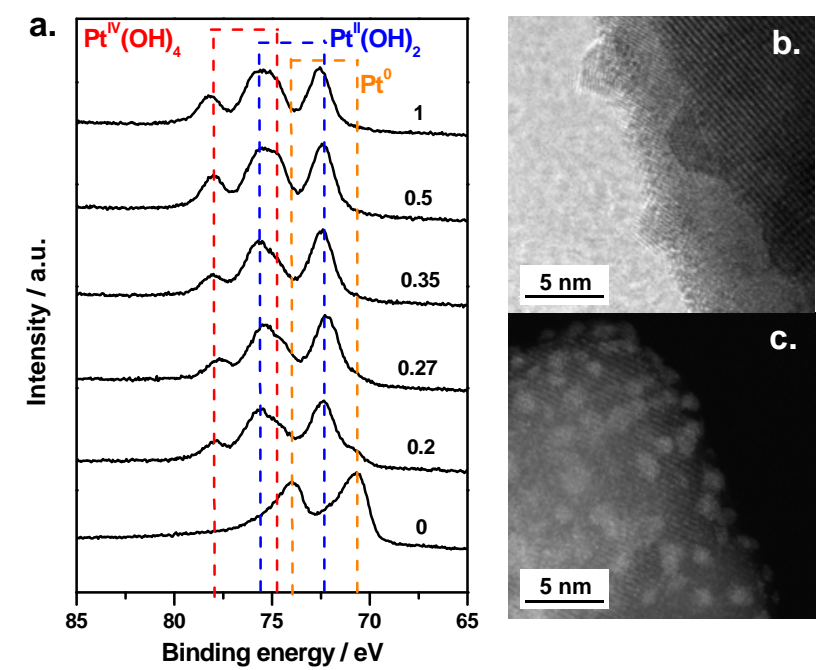

Fig. 2. Valence states and morphologies of the cocatalysts. (a) XPS spectra of $\mathrm{Pt} 4 f$ of cocatalysts with different $\mathrm{Cr} / \mathrm{Pt}$ mass ratios; (b) HR-TEM image of Pt-ZrO $/ \mathrm{TaON}$; (c) HAADF-STEM image of $\mathrm{PtCrO}_{x}$ $(0.5)-\mathrm{ZrO}_{2} / \mathrm{TaON}$. the Pt peak at the high binding energy increased slightly after the photoreaction (Fig. S2(a)), probably due to the adsorption of hexacyanoferrate on $\mathrm{Pt}$ through the highly polar $\mathrm{CN}^{-}$, as also found by some researchers that a surface species containing $\mathrm{Pt}-\mathrm{CN}$ was formed after the redox reaction of $\mathrm{Fe}(\mathrm{CN}) 6^{3-} / \mathrm{Fe}(\mathrm{CN})_{6}{ }^{4-}$ on the $\mathrm{Pt}$ electrode [29-31]. For $\mathrm{PtCrO}_{x}(0.5)-\mathrm{ZrO}_{2} / \mathrm{TaON}$, the electronic states of $\mathrm{Pt}$ and $\mathrm{Cr}$ were well-sustained after the photoreaction (Fig. S2(b)), indicating the stable configuration of $\mathrm{PtCrO}_{x}$ during the proton reduction process, which is consistent with the stable HER performance. It is well-known that the photogenerated electrons aggregate on the HER cocatalyst for proton production, but the high oxidation states of $\mathrm{Pt}^{\mathrm{II}}$ and $\mathrm{Pt}^{\mathrm{IV}}$ in the $\mathrm{PtCrO}_{x}$ cocatalyst could still be well-sustained without being reduced into metallic Pt during the HER process. The coordination function of the $\mathrm{CrO}_{x}$ species to $\mathrm{PtI}^{\mathrm{II}}$ and $\mathrm{Pt} \mathrm{IV}^{\mathrm{IV}}$ might contribute to the good stability of $\mathrm{PtCrO}_{x}$.

Morphologies of the cocatalysts were observed by HR-TEM. In the absence of $\mathrm{Cr}$, metallic Pt particles with a diameter of $\sim 5$ $\mathrm{nm}$ and a lattice fringe of $\mathrm{Pt}$ (111) were observed on the $\mathrm{ZrO}_{2} / \mathrm{TaON}$ surface (Fig. 2(b)). Upon addition of $\mathrm{Cr}$, amorphous $\mathrm{PtCrO}_{x}$ clusters without any distinct lattice fringe formed on the substrate, with a size of $\sim 2 \mathrm{~nm}$, much smaller than the Pt particles (Fig. S3). It was noted that on the sample with a low $\mathrm{Cr} / \mathrm{Pt}$ ratio of 0.2 , a spot of the metallic Pt particles could still be found (inset of Fig. S3(a)), in agreement with the small proportion of the $\mathrm{Pt}^{0}$ XPS peaks. This suggests that during the photodeposition process, the redundant Pt precursor that did not form $\mathrm{PtCrO}_{x}$ was finally reduced into metallic Pt particles. Considering the limitation of resolution of HR-TEM, the small $\mathrm{PtCrO}_{x}$ particles on $\mathrm{PtCrO}_{x}(0.5)-\mathrm{ZrO}_{2} / \mathrm{TaON}$ were further confirmed by HAADF-STEM, and small bright dots were found to distribute in the $\mathrm{PtCrO}_{x}$ clusters, which are considered as the $\mathrm{Pt}$ species with a heavy atomic weight (Fig. 2(c)). Compared with the metallic Pt particles, the $\mathrm{PtCrO}_{x}$ clusters are able to provide more active sites for the proton reduction due to the larger surface area of smaller particles.

\subsection{Backward reactions on different cocatalysts}

When $\mathrm{Fe}(\mathrm{CN})_{6}{ }^{4-}$ acts as an electron donor in the HER, hydrogen evolution is accompanied by the production of $\mathrm{Fe}(\mathrm{CN})_{6}{ }^{3-}$. The forward activity might be hindered by the backward reactions shown in Eqs. (1) and (2).

$$
\begin{gathered}
\mathrm{Fe}(\mathrm{CN})_{6} 6^{3-}+\mathrm{e}^{-} \rightarrow \mathrm{Fe}(\mathrm{CN})_{6} 4^{--} \\
2 \mathrm{Fe}(\mathrm{CN})_{6^{3-}}+\mathrm{H}_{2} \rightarrow 2 \mathrm{Fe}(\mathrm{CN})_{6} 6^{--}+2 \mathrm{H}^{+}
\end{gathered}
$$

It can be noted that both the backward reactions involve the reduction of $\mathrm{Fe}(\mathrm{CN}) 6^{3-}$ and ultimately affect hydrogen production. In the case of Eq. (1), $\mathrm{Fe}(\mathrm{CN})_{6} 6^{3-}$ competitively reacts with the photogenerated electrons which are expected to reduce protons for hydrogen production, while in the case of Eq. (2), the produced hydrogen gas might be consumed due to hydrogen oxidation by $\mathrm{Fe}(\mathrm{CN})_{6}{ }^{3-}$.

Some control experiments were carried out to investigate the backward reactions in the HER. Hydrogen evolution on $\mathrm{Pt}-\mathrm{ZrO}_{2} / \mathrm{TaON}$ with methanol as an electron donor was measured both in the absence and presence of $\mathrm{Fe}(\mathrm{CN})_{6}{ }^{3-}$. As shown in Fig. S4(a), the activity declined by seven times after adding 1 
$\mathrm{mM} \mathrm{Fe}(\mathrm{CN}) 6^{3-}$, and $\mathrm{Fe}(\mathrm{CN})_{6} 6^{3-}$ was reduced to $\mathrm{Fe}(\mathrm{CN})_{6}{ }^{4-}$, as indicated by the UV-Vis absorption spectrum (Fig. S4(b)). Subsequently, the decline in hydrogen evolution on $\mathrm{PtCrO}_{x}-\mathrm{ZrO}_{2} / \mathrm{TaON}$ as a function of $\mathrm{Fe}(\mathrm{CN})_{6}{ }^{3-}$ concentration was investigated. To avoid light being blocked by the $\mathrm{Fe}(\mathrm{CN}) 6^{3-}$ solution, the lamp was equipped with a long-pass filter $(\lambda \geq 480$ $\mathrm{nm})$. As shown in Fig. S5, among the three samples with different $\mathrm{Cr} / \mathrm{Pt}$ mass ratios $(0.2,0.35$, and 0.5), $\mathrm{PtCrO}_{x}(0.5)-\mathrm{ZrO}_{2} / \mathrm{TaON}$ showed the slowest activity decline along with the increasing $\mathrm{Fe}(\mathrm{CN})_{6}{ }^{3-}$ concentration, while hydrogen production on $\mathrm{PtCrO}_{x}(0.2)-\mathrm{ZrO}_{2} / \mathrm{TaON}$, which contained a spot of the metallic Pt cocatalyst, was almost quenched in $5 \mathrm{mM} \mathrm{Fe}(\mathrm{CN})_{6}{ }^{3-}$. These results indicate that the presence of $\mathrm{Fe}(\mathrm{CN})_{6}{ }^{3-}$ indeed lowers the hydrogen production activity, especially for the photocatalyst loaded with metallic Pt. $\mathrm{PtCrO}_{x}(0.5)-\mathrm{ZrO}_{2} / \mathrm{TaON}$ containing only the $\mathrm{Pt}^{\mathrm{II}}$ and $\mathrm{Pt} \mathrm{tV}^{\mathrm{IV}}$ species shows the best capability to block the backward reaction.

Furthermore, the redox reaction between hydrogen and $\mathrm{Fe}(\mathrm{CN})_{6}{ }^{3-}$ was investigated in the dark in the presence and absence of photocatalysts. The corresponding changes in the amount of hydrogen and the $\mathrm{Fe}(\mathrm{CN}) 6^{3-}$ concentration are shown in Fig. 3(a) and Fig. S6, respectively. It was found that both, the amount of hydrogen and the concentration of $\mathrm{Fe}(\mathrm{CN}) 6^{3-}$, remained unchanged if there was no photocatalyst in the solution, indicating that the redox reaction did not take place. Even in the presence of $\mathrm{PtCrO}_{x}-\mathrm{ZrO}_{2} / \mathrm{TaON}$ $\left(\mathrm{PtCrO}_{x}-\mathrm{ZrO}_{2} / \mathrm{TaON}\right.$ hereafter represents the sample with a $\mathrm{Cr} / \mathrm{Pt}$ mass ratio of 0.5 , unless otherwise noted), the redox reaction did not take place. However, in the presence of $\mathrm{Pt}-\mathrm{ZrO}{ }_{2} / \mathrm{TaON}$, the amount of hydrogen decreased obviously and $\mathrm{Fe}(\mathrm{CN})_{6}{ }^{3-}$ was transformed into $\mathrm{Fe}(\mathrm{CN})_{6}{ }^{4-}$. To ensure sufficient contact between hydrogen, $\mathrm{Fe}(\mathrm{CN})_{6}{ }^{3-}$, and the photocatalyst, hydrogen was bubbled into the reaction solution. Similarly, as shown in Fig. $3(\mathrm{~b}), \mathrm{Fe}(\mathrm{CN}) 6^{3-}$ remained unchanged in the absence of the photocatalyst or in the presence of $\mathrm{PtCrO}_{x}-\mathrm{ZrO}_{2} / \mathrm{TaON}$, whereas almost all $\mathrm{Fe}(\mathrm{CN})_{6}{ }^{3-}$ in the solution was reduced in $15 \mathrm{~min}$ in the presence of $\mathrm{Pt}-\mathrm{ZrO}_{2} / \mathrm{TaON}$. These results indicate that the kinetically controlled backward reaction of hydrogen oxidation by $\mathrm{Fe}(\mathrm{CN})_{6}{ }^{3-}$ was remarkably accelerated via the catalytic action of the metallic Pt particles, resulting in the remarkable hydrogen loss in the HER. On the contrary, $\mathrm{PtCrO}_{x}$ oxide did not catalyze this backward reaction; thus, hydrogen could evolve even in the presence of $\mathrm{Fe}(\mathrm{CN}) 6^{3-}$.

Subsequently, surface interactions between the cocatalysts ( $\mathrm{Pt}$ and $\left.\mathrm{PtCrO}_{x}\right)$ and the reactants $\left(\mathrm{Fe}(\mathrm{CN})_{6} 6^{3-}\right.$ and hydrogen) were investigated to understand their different catalytic behavior. Zeta potentials of $\mathrm{Pt}-\mathrm{ZrO}_{2} / \mathrm{TaON}$ and $\mathrm{PtCrO}_{x}-\mathrm{ZrO}_{2} / \mathrm{TaON}$ in the reaction buffer solution (PBS buffer, $\mathrm{pH}=6$ ) were found to be about -24 and $-19 \mathrm{mV}$, respectively, suggesting that there are no electrostatic attractions between $\mathrm{Fe}(\mathrm{CN}) 6^{3-}$ ions and the electronegative photocatalyst surface. The adsorption tests showed that there is no chemical or physical adsorption of $\mathrm{Fe}(\mathrm{CN})_{6}{ }^{3-}$ on the surface of both $\mathrm{Pt}_{-} \mathrm{ZrO}_{2} / \mathrm{TaON}$ and $\mathrm{PtCrO}_{x}-\mathrm{ZrO}_{2} / \mathrm{TaON}$. Moreover, it has been well-convinced that hydrogen molecules can be chemisorbed on the metallic Pt surface strongly and dissociate into highly active atomic $\mathrm{H}^{*}$ [32-35]. In contrast, the adsorption and activation of hydrogen molecules on the metal oxide surface was reported to be much weaker [35]. Therefore, it is reasonable to speculate that the difference in the catalytic behavior of $\mathrm{Pt}$ and $\mathrm{PtCrO}_{x}$ in hydrogen oxidation by $\mathrm{Fe}(\mathrm{CN})_{6}{ }^{3-}$ is mainly due to the different adsorption and activation performances of hydrogen on their surfaces.

\subsection{Electrochemical reduction performances of different cocatalysts}

To obtain further insights into the function of cocatalysts on the forward and backward reactions, the electrochemical behavior of proton and $\mathrm{Fe}(\mathrm{CN})_{6}{ }^{3-}$ reduction was measured for $\mathrm{ZrO}_{2} / \mathrm{TaON}, \mathrm{Pt}-\mathrm{ZrO}_{2} / \mathrm{TaON}$, and $\mathrm{PtCrO}_{x}-\mathrm{ZrO}_{2} / \mathrm{TaON}$-covered FTO electrodes. In Fig. 4(a), the LSV curves show that the reduction peaks of $\mathrm{Fe}(\mathrm{CN}) 6^{3-}$ emerge at more positive potentials than those of hydrogen evolution for all the samples. The Pt-loaded sample exhibits the highest hydrogen evolution current, but the most positive onset potential for $\mathrm{Fe}(\mathrm{CN})_{6}{ }^{3-}$ reduction. For the $\mathrm{PtCrO}_{x}$-loaded sample, the proton reduction performance is not so good, but it possesses the most negative
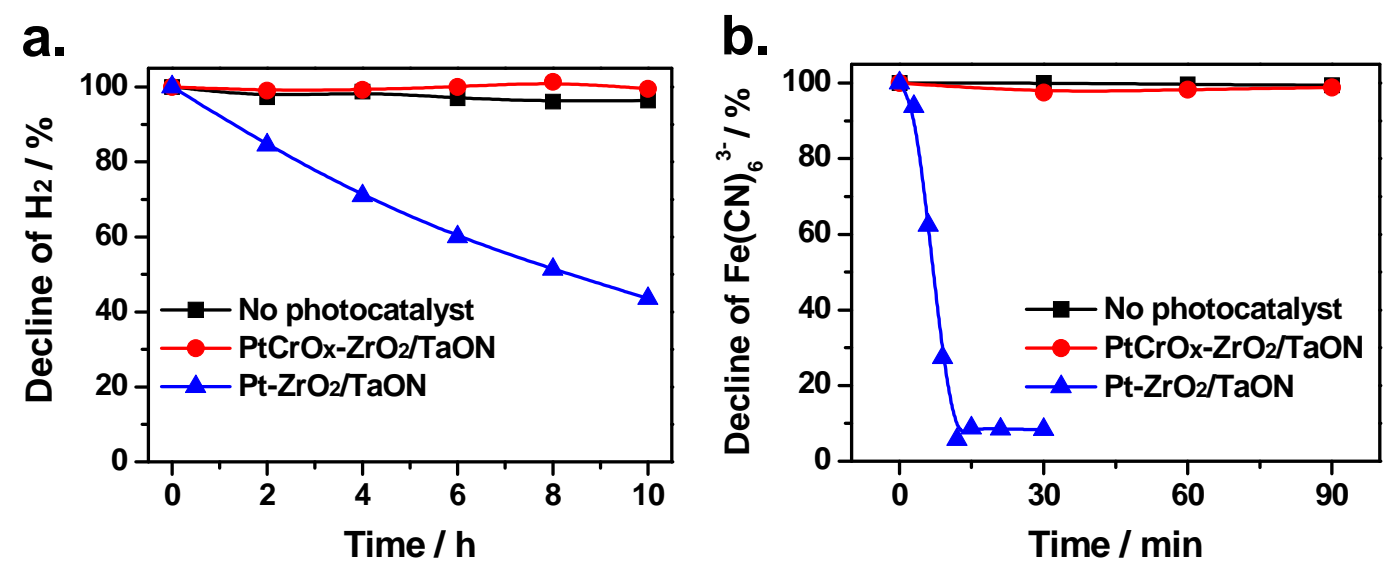

Fig. 3. Backward reaction performances between hydrogen and $\mathrm{Fe}(\mathrm{CN})_{6}{ }^{3-}$. (a) Decline percentage of $7 \mu \mathrm{mol}$ hydrogen in the dark reaction in 2 mM $\mathrm{Fe}(\mathrm{CN})_{6}{ }^{3-}$ with different photocatalysts; (b) Decline percentage of $2 \mathrm{mM} \mathrm{Fe}(\mathrm{CN})_{6}{ }^{3-}$ in the dark reaction under $\mathrm{H}_{2}$ bubbling with different photocatalysts. 

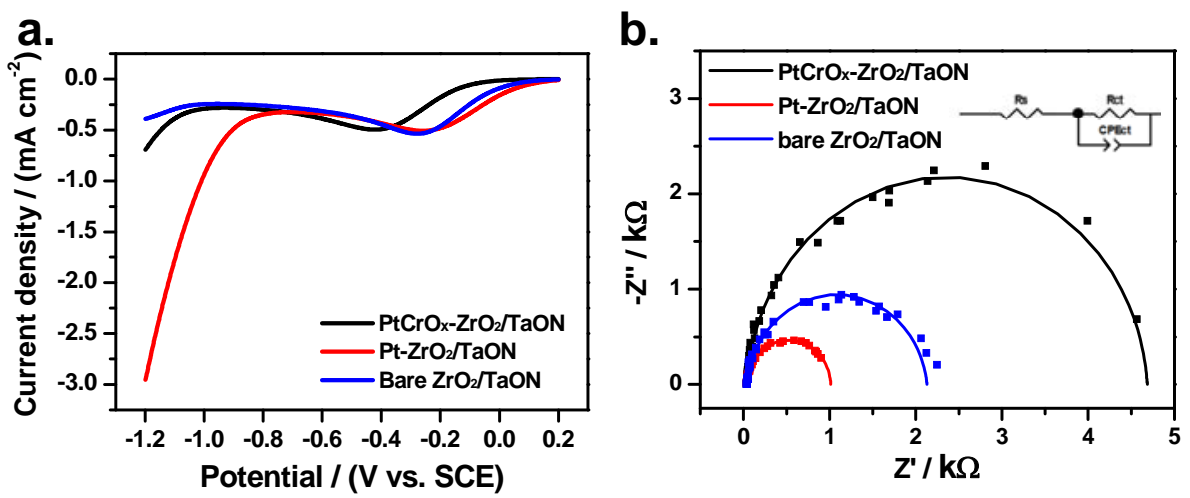

Fig. 4. Electrochemical performances of cocatalyst-loaded $\mathrm{ZrO}_{2} / \mathrm{TaON}$ electrodes. (a) LSV curves for the reduction of both Fe(CN) $6^{3-}$ and proton; (b) EIS performances of the electrodes in the electrochemical Fe $(\mathrm{CN})_{6}{ }^{3-}$ reduction at $-0.2 \mathrm{~V}$ (vs. SCE).

onset potential for $\mathrm{Fe}(\mathrm{CN}) 6^{3-}$ reduction. To further clarify the charge transfer of $\mathrm{Fe}(\mathrm{CN})_{6}{ }^{3-}$ reduction at the solution-electrode interface, EIS was performed at an applied potential of $-0.2 \mathrm{~V}$ vs. SCE, which is negative enough for $\mathrm{Fe}(\mathrm{CN})_{6}{ }^{3-}$ reduction, but not for proton reduction. The Nyquist curves are shown in Fig. 4(b) and the values of the charge transfer resistance (Rct) are given in Table S1. The order of Rct $\left(\mathrm{PtCrO}_{x}>\right.$ bare $\left.>\mathrm{Pt}\right)$ also confirms the favorable kinetics of $\mathrm{Fe}(\mathrm{CN}) 6^{3-}$ reduction on metallic $\mathrm{Pt}$ and the unfavorable kinetics of $\mathrm{Fe}(\mathrm{CN}) 6^{3-}$ reduction on $\mathrm{PtCrO}_{x}$. As a consequence, even though $\mathrm{PtCrO}_{x}$ is not as good as Pt in catalyzing proton reduction, it conducts the slowest $\mathrm{Fe}(\mathrm{CN})_{6}{ }^{3-}$ reduction, which is more important for achieving sustainable hydrogen evolution.

\subsection{Overall water splitting in PSII-integrated hybrid Z-scheme system}

Finally, a PSII-integrated hybrid Z-scheme system was constructed for the overall water splitting reaction with $\mathrm{PtCrO}_{x}-\mathrm{ZrO}_{2} / \mathrm{TaON}$ as the HER photocatalyst and $\mathrm{Fe}(\mathrm{CN})_{6}{ }^{4-} / \mathrm{Fe}(\mathrm{CN}) 6^{3-}$ as the electron mediator. The water oxidation rate of PSII has been demonstrated to be greatly dependent on the concentration of the exogenous electron accep- tor, $\mathrm{Fe}(\mathrm{CN}) 6^{3-}$, in the previous work [16]. Benefiting from the high selectivity of the $\mathrm{Mn}_{4} \mathrm{CaO}_{5}$ cluster and $\mathrm{Q}_{\text {B }}$ pocket of PSII for water oxidation and $\mathrm{Fe}(\mathrm{CN})_{6}{ }^{3-}$ reduction, no backward reactions or other side reactions were observed.

During the overall water splitting process, the initial $\mathrm{H}_{2}$ and $\mathrm{O}_{2}$ evolution rates are kinetically controlled and strongly dependent on the concentration of the electron donor or acceptor. As shown in Fig. 5(a), when $100 \% \mathrm{Fe}(\mathrm{CN}) 6^{3-}(10 \mathrm{mM}$ $\mathrm{Fe}(\mathrm{CN}) 6^{3-}$ ) was used as the initial electron mediator with no $\mathrm{Fe}(\mathrm{CN}) 6^{4-}$ supplied, $\mathrm{O}_{2}$ evolution by PSII is considerably high, whereas $\mathrm{H}_{2}$ evolution by $\mathrm{PtCrO}_{x}-\mathrm{ZrO}_{2} / \mathrm{TaON}$ is much less, which is comprehensible as the concentration of transformed $\mathrm{Fe}(\mathrm{CN})_{6}{ }^{4-}$ is definitely low. On the contrary, $\mathrm{O}_{2}$ is much more slowly produced than $\mathrm{H}_{2}$ when $100 \% \mathrm{Fe}(\mathrm{CN})_{6}{ }^{4-}$ was used initially. It is predictable that the stoichiometric ratio of $\mathrm{H}_{2}$ to $\mathrm{O}_{2}$ would approach 2:1 at some point, along with the concentration change of the mediator ions during the water splitting process. However, taking into consideration the gradual photodegradation of PSII, it is better to offer an optimal concentration of the shuttle ions at the initial stage for the stoichiometric water splitting. To simulate the mutual transformation of $\mathrm{Fe}(\mathrm{CN})_{6}{ }^{4-/ 3-}$ during the water splitting process, the total concentration of the shuttle ions was fixed at $10 \mathrm{mM}$, and their
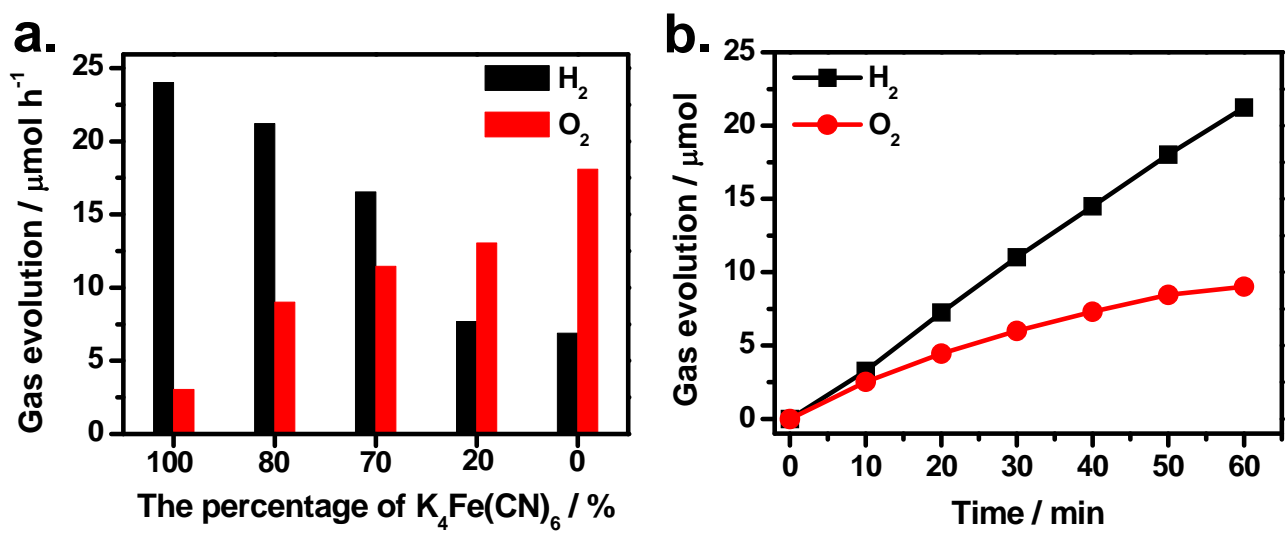

Fig. 5. (a) Overall water splitting activities dependent on the percentage of $\mathrm{Fe}(\mathrm{CN})_{6}{ }^{4-}$. The total concentration of $\mathrm{Fe}(\mathrm{CN}) 6^{3-}$ and $\mathrm{Fe}(\mathrm{CN}) 6^{4-}$ is $10 \mathrm{mM}$. (b) Time course of overall water splitting activity at $80 \% \mathrm{Fe}(\mathrm{CN})_{6}{ }^{4-}\left(8 \mathrm{mM} \mathrm{Fe}(\mathrm{CN})_{6}{ }^{4-}, 2 \mathrm{mM} \mathrm{Fe}(\mathrm{CN})_{6}{ }^{3-}\right) .20 \mathrm{mg} \mathrm{Cr} / \mathrm{Pt}(0.5)-\mathrm{ZrO}{ }_{2} / \mathrm{TaON}$ and $150 \mu \mathrm{Chl}$ of PSII were dispersed in $20 \mathrm{ml}$ PBS buffer $(\mathrm{pH}=6)$. Temperature: $25^{\circ} \mathrm{C}$. Light source: AM $1.5 \mathrm{G}$. 
relative proportions were modulated to several possible points with the percentage of $\mathrm{Fe}(\mathrm{CN})_{6}{ }^{4-}$ being $80 \%, 70 \%$, and $20 \%$. As expected, hydrogen evolution decreased and oxygen evolution increased regularly with the decline of the $\mathrm{Fe}(\mathrm{CN})_{6}{ }^{4-}$ proportion, and the stoichiometric splitting of water into ca. $20 \mu \mathrm{mol}$ $\mathrm{H}_{2} \mathrm{~h}^{-1}$ and $10 \mu \mathrm{mol} \mathrm{O}_{2} \mathrm{~h}^{-1}$ was achieved at $8 \mathrm{mM} \mathrm{Fe}(\mathrm{CN}) 6^{4-}$ and $2 \mathrm{mM} \mathrm{Fe}(\mathrm{CN})_{6}{ }^{3-}$. The corresponding time courses of gas evolution are shown in Fig. 5(b).

\subsection{Proposed mechanisms for the blockage of the backward reactions}

In this PSII- $\mathrm{PtCrO}_{x}$-ZrO 2 /TaON Z-scheme system, due to the original favorable water oxidation performance of PSII, the key point to realize a successful overall water splitting in the presence of both $\mathrm{Fe}(\mathrm{CN})_{6}{ }^{3-}$ and $\mathrm{Fe}(\mathrm{CN})_{6}{ }^{4-}$ lies in the improved HER on $\mathrm{PtCrO}_{x}-\mathrm{ZrO}_{2} / \mathrm{TaON}$ without any major backward reactions. According to the results and analyses above, the mechanisms of the generation and suppression of $\mathrm{Fe}(\mathrm{CN})_{6}{ }^{3-}$ reduction involved in the backward reactions on metallic Pt and oxide $\mathrm{PtCrO}_{x}$ cocatalysts can be proposed reasonably. Owing to the negligible interactions between $\mathrm{Fe}(\mathrm{CN})_{6}{ }^{3-}$ and the surfaces of the two photocatalysts, hydrogen oxidation by $\mathrm{Fe}(\mathrm{CN}) 6^{3-}$ (Eq. (2)) is considered as the major backward reaction to block the forward HER. As shown in Fig. 6(a), metallic Pt loaded on $\mathrm{ZrO}_{2} / \mathrm{TaON}$ not only catalyzes proton reduction to produce hydrogen, but also catalyzes the backward reaction that results in hydrogen oxidation by $\mathrm{Fe}(\mathrm{CN})_{6} 6^{3-}$ due to the activation of adsorbed hydrogen. Therefore, molecular $\mathrm{H}_{2}$ and $\mathrm{H}^{*}$ interme- diate can be oxidized by $\mathrm{Fe}(\mathrm{CN})_{6}{ }^{3-}$ rapidly, with a negligible amount of hydrogen gas being evolved. However, for the $\mathrm{PtCrO}_{x}$-loaded $\mathrm{ZrO}_{2} / \mathrm{TaON}$ sample, hydrogen adsorption on $\mathrm{PtCrO}_{x}$ is much weaker so that the backward reaction would not be catalyzed (Fig. 6(b)). Although the proton reduction on $\mathrm{PtCrO}_{x}$ is not so efficient as that on metallic $\mathrm{Pt}$, the net hydrogen production performance on $\mathrm{PtCrO}_{x}-\mathrm{ZrO}_{2} / \mathrm{TaON}$ becomes much better than that on $\mathrm{Pt}-\mathrm{ZrO}_{2} / \mathrm{TaON}$ due to the relatively better suppressed backward reactions. In addition, stable $\mathrm{PtCrO}_{x}$ during the photocatalytic reduction process with no reduction of the $\mathrm{Pt}^{\mathrm{II}}$ and $\mathrm{Pt}^{\mathrm{IV}}$ species helps to maintain sustainable hydrogen production. As a consequence, Z-scheme overall water splitting into $\mathrm{H}_{2}$ and $\mathrm{O}_{2}$ can be realized by combining PSII with $\mathrm{PtCrO}_{x}-\mathrm{ZrO}_{2} / \mathrm{TaON}$ via the $\mathrm{Fe}(\mathrm{CN})_{6}^{3-/ 4-}$-mediated forward electron transfer (Fig. 6(c)).

\section{Conclusions}

In summary, the present work has demonstrated the suppression of the backward hydrogen oxidation reactions caused by the electron shuttle, $\mathrm{Fe}(\mathrm{CN})_{6}{ }^{3-}$, in a $\mathrm{PSII}-\mathrm{ZrO}_{2} / \mathrm{TaON}$ hybrid system for Z-scheme water splitting. Serious hydrogen oxidation by $\mathrm{Fe}(\mathrm{CN}) 6^{3-}$ took place under the catalysis of the metallic Pt cocatalyst loaded on $\mathrm{ZrO}_{2} / \mathrm{TaON}$ and blocked the forward HER. By introducing the oxide $\mathrm{PtCrO}_{x}$ which contains stable PtII and $\mathrm{Pt}^{\mathrm{IV}}$ species to replace metallic $\mathrm{Pt}$ as the cocatalyst, hydrogen oxidation was greatly suppressed owing to the lack of adsorption and activation of hydrogen on $\mathrm{PtCrO}_{x}$, thus leading to a remarkable enhancement in the hydrogen producing activity.

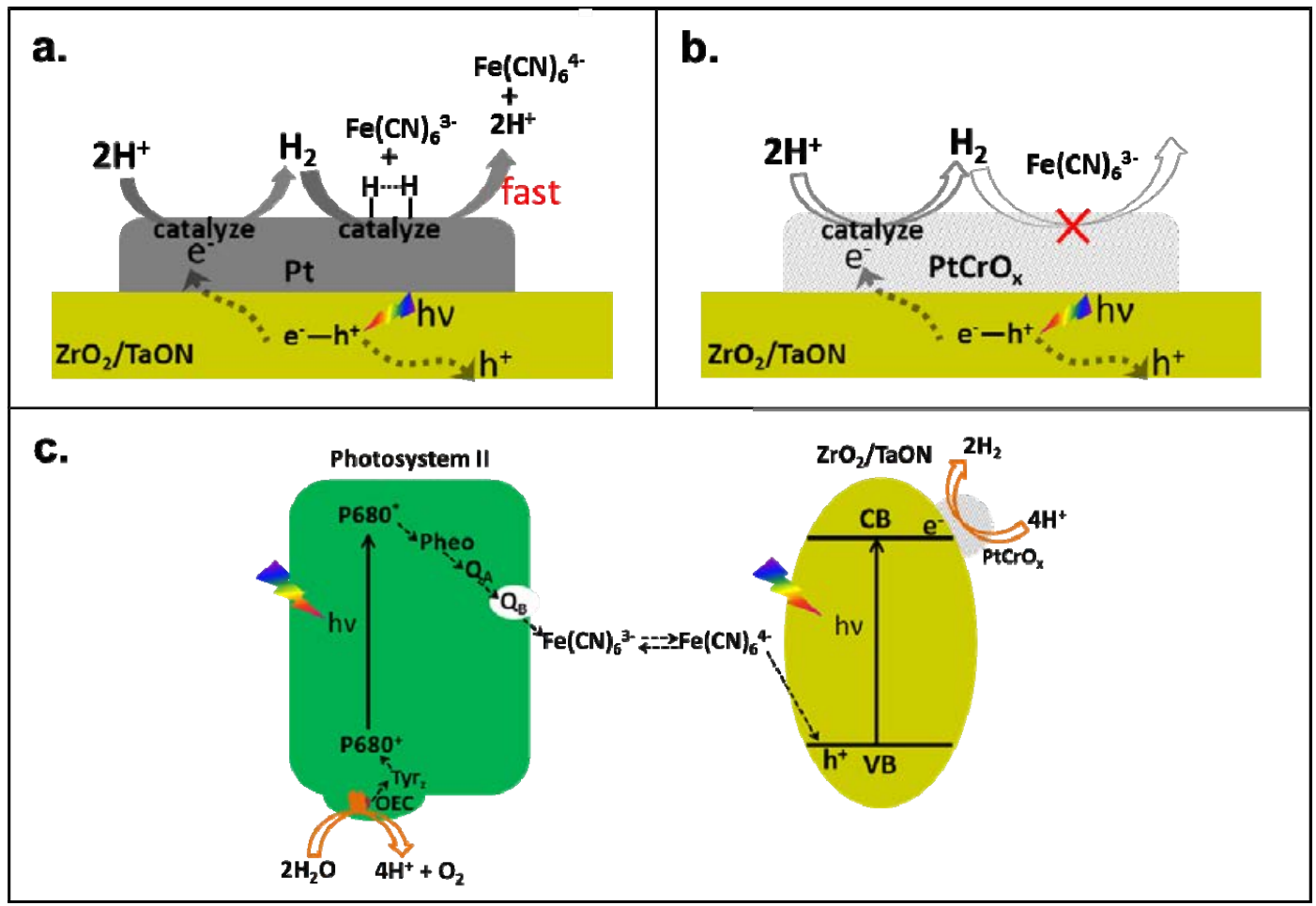

Fig. 6. Schematic representation of the generation and suppression of the backward reaction on $\mathrm{Pt}_{-}$loaded $\mathrm{ZrO}_{2} / \mathrm{TaON}(\mathrm{a}), \mathrm{PtCrO}_{x}$-loaded $\mathrm{ZrO} \mathrm{O}_{2} / \mathrm{TaON}$ (b), and the PSII-ZrO $\mathrm{Zr}_{2} / \mathrm{TaON}$ hybrid Z-scheme (c) overall water splitting process. 


\section{Graphical Abstract}

Chin. J. Catal., 2019, 40: 486-494 doi: S1872-2067(19)63311-5

Blocking backward reaction on hydrogen evolution cocatalyst in a photosystem II hybrid Z-scheme water splitting system

Zhen Li, Yu Qi, Wangyin Wang, Deng Li, Zheng Li, Yanan Xiao, Guangye Han, Jian-Ren Shen, Can Li*

Dalian Institute of Chemical Physics, Chinese Academy of Sciences, China;

Institute of Botany, Chinese Academy of Sciences, China;

University of Chinese Academy of Sciences, China;

Okayama University, Japan

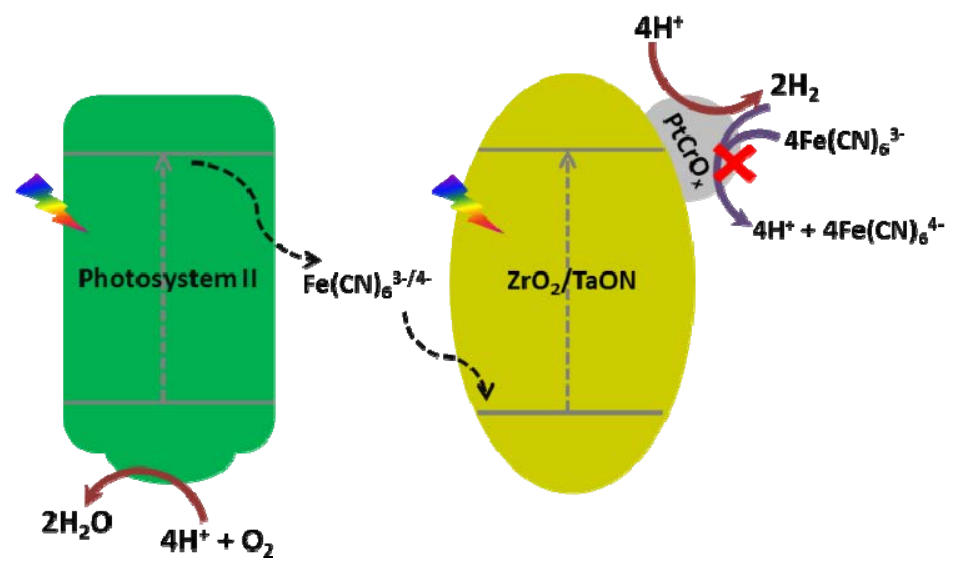

Hydrogen evolution cocatalyst, $\mathrm{PtCrO}_{x}$, is loaded on $\mathrm{ZrO}_{2} / \mathrm{TaON}$ to block the backward hydrogen oxidation reaction by $\mathrm{Fe}(\mathrm{CN})_{6}^{3-}$, pro-

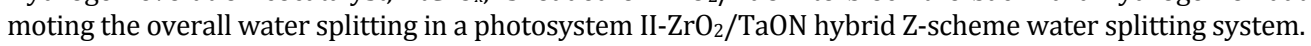

This work provides new opportunities for the inhibition of the backward reaction when using $\mathrm{Fe}(\mathrm{CN}) 6^{3-/ 4-}$ as the electron shuttle to build the PSII-semiconductor hybrid water splitting system.

\section{References}

[1] R. E. Blankenship, Photosynth. Res., 1992, 33, 91-111.

[2] P. Joliot, G. N. Johnson, Proc. Natl. Acad. Sci., 2011, 108, 13317-13322.

[3] J. Barber, Chem. Soc. Rev., 2009, 38, 185-196.

[4] A. N. Tikhonov, Plant Physiol. Biochem., 2014, 81, 163-183.

[5] F. Muh, C. Glockner, J. Hellmich, A. Zouni, Biochim. Biophys. Acta, 2012, 1817, 44-65.

[6] K. Maeda, ACS Catal., 2013, 3, 1486-1503.

[7] P. Zhou, J. Yu, M. Jaroniec, Adv. Mater., 2014, 26, 4920-4935.

[8] K. Maeda, J. Photochem. Photobiol. C, 2011, 12, 237-268.

[9] S. Chen, T. Takata, K. Domen, Nat. Rev. Mater., 2017, 2, 17050.

[10] R. Abe, K. Shinmei, N. Koumura, K. Hara, B. Ohtani, J. Am. Chem. Soc., 2013, 135, 16872-16884.

[11] Y. Sasaki, A. Iwase, H. Kato, A. Kudo, J. Catal., 2008, 259, 133-137.

[12] T. Ohno, D. Haga, K. Fujihara, K. Kaizaki, M. MAtsumura, J. Phys. Chem. B, 1997, 101, 6415-6419.

[13] Y. Miseki, S. Fujiyoshi, T. Gunji, K. Sayama, Catal. Sci. Technol., 2013, 3, 1750-1756.

[14] R. Abe, K. Sayama, H. Sugihara, J. Phys. Chem. B, 2005, 109, 16052-16061.

[15] W. Wang, J. Chen, C. Li, W. Tian, Nat. Commun., 2014, 5, 4647.
[16] W. Wang, H. Wang, Q. Zhu, W. Qin, G. Han, J. R. Shen, X. Zong, C. Li, Angew. Chem. Int. Ed., 2016, 55, 9229-9233.

[17] D. Mersch, C. Y. Lee, J. Z. Zhang, K. Brinkert, J. C. Fontecilla-Camps, A. W. Rutherford, E. Reisner, J. Am. Chem. Soc., 2015, 137, 8541-8549.

[18] K. Min, Y. J. Yoo, Biotechnol. Bioprocess Eng., 2014, 19, 553-567.

[19] M. Suga, F. Akita, M. Sugahara, M. Kubo, Y. Nakajima, T. Nakane, K. Yamashita, Y. Umena, M. Nakabayashi, T. Yamane, T. Nakano, M. Suzuki, T. Masuda, S. Inoue, T. Kimura, T. Nomura, S. Yonekura, L. J. Yu, T. Sakamoto, T. Motomura, J. H. Chen, Y. Kato, T. Noguchi, K. Tono, Y. Joti, T. Kameshima, T. Hatsui, E. Nango, R. Tanaka, H. Naitow, Y. Matsuura, A. Yamashita, M. Yamamoto, O. Nureki, M. Yabashi, T. Ishikawa, S. Iwata, J. R. Shen, Nature, 2017, 543, 131-135.

[20] J. W. Lee, E. Greenbaum, J. Phys. Chem. B, 2004, 108, 3935-3939.

[21] K. Maeda, M. Higashi, D. Lu, R. Abe, K. Domen, J. Am. Chem. Soc., 2010, 132, 5858-5868.

[22] J. R. Shen, N. Kamiya, Biochemistry, 2000, 39, 14739-14744.

[23] J. R. Shen, Y. Inoue, Biochemistry, 1993, 32, 1825-1832.

[24] P. J. Porra, W. A. Thompson, P. E. Kriedemann, Biochim. Biophys. Acta, 1989, 975, 384-394.

[25] Y. Umena, K. Kawakami, J. R. Shen, N. Kamiya, Nature, 2011, 473, 55-60.

[26] K. Maeda, H. Terashima, K. Kase, M. Higashi, M. Tabata, K. Domen, Bull. Chem. Soc. Jpn., 2008, 81, 927-937.

[27] S. S. K. Ma, K. Maeda, K. Domen, Catal. Sci. Technol, 2012, 2, 818-823.

[28] K. Maeda, M. Higashi, D. Lu, R. Abe, K. Domen, J. Am. Chem. Soc., 2010, 132, 5858-5868. 
[29] M. Stieble, K. Juttner, J. Electroanal. Chem., 1990, 290, 163-180.

[30] K. Kunimatsu, Y. Shigematsu, K. Uosaki, H. Kita, J. Electroanal. Chem., 1989, 262, 195-209.

[31] A. Wieckowski, M. Szklarczyk, J. Electroanal. Chem., 1982, 142, 157-170.

[32] J. T. Miller, B. L. Meyers, F. S. Modica, G. S. Lane, M. Vaarkamp, D. C.
Koningsberger, J. Catal., 1993, 143, 395-408.

[33] Y. Nishiyama, H. Wise, J. Catal. , 1974, 32, 50-62.

[34] S. Tsuchiya, Y. Amenoniya, J. Cvetanovic, J. Catal., 1970, 19, 245-255.

[35] Y. H. Li, J. Xing, Z. J. Chen, Z. Li, F. Tian, L. R. Zheng, H. F. Wang, P. Hu, H. J. Zhao, H. G. Yang, Nat. Commun., 2013, 4, 2500.

\title{
光系统II杂化Z型水分解体系中产氢助催化剂上逆反应的抑制
}

\author{
李 真 ${ }^{\mathrm{a}, \mathrm{b}}$, 衩 育 ${ }^{\mathrm{a}}$, 王旺银, 李 登, ${ }^{\mathrm{a}, \mathrm{b}}$, 李 政 ${ }^{\mathrm{a}, \mathrm{b}}$, 肖亚男 ${ }^{\mathrm{b}, \mathrm{c}}$, 韩广业 ${ }^{\mathrm{c}}$, 沈建仁 ${ }^{\mathrm{c}, \mathrm{d}}$, 李 灿, ${ }^{\mathrm{a}}$ \\ a中国科学院大连化学物理研究所, 催化基础国家重点实验室, 洁净能源国家实验室(筹), \\ 能源材料化学协同创新中心, 辽宁大连116023, 中国

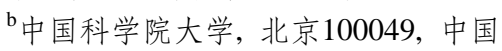 \\ c中国科学院植物研究所, 光生物学重点实验室, 光合作用研究中心, 北京100093, 中国 \\ d冈山大学, 自然科学与技术研究生院, 交叉科学研究所, 冈山 $700-8530$, 日本
}

摘要: 光催化Z型水分解反应有望发展成为一种生产太阳氢能的有效方法. 将具有优异水氧化性能的自然光系统II与人工 半导体产氢材料进行耦合, 以构建生物-人工杂化光催化Z型水分解反应体系, 对于深入理解自然光合作用原理和促进人工 太阳能转化具有重要意义. 由于 $\mathrm{Fe}(\mathrm{CN})_{6}{ }^{3-}$ 可从光系统II接受电子, 因此氧化还原电对 $\mathrm{Fe}(\mathrm{CN})_{6}{ }^{3-4}$-成为研究光系统II基杂化 Z 型水分解体系时常用的电子体递. 然而, 在该Z型水分解反应中, 正向的产氢反应经常受到由 $\mathrm{Fe}(\mathrm{CN})_{6}{ }^{3}$ 引起的逆反应的阻 碍, 致使水分解过程中产氢产氧失衡, 不能实现有效的全分解水反应. 本文通过在光系统II杂化Z型水分解体系中的人工光 催化剂 $\mathrm{ZrO}_{2} / \mathrm{TaON}$ 上沉积产氢助催化剂 $\mathrm{PtCrO}_{x}$, 有效抑制了逆反应的发生, 从而使体系实现了全分解水反应.

实验发现, 在光催化剂 $\mathrm{ZrO}_{2} / \mathrm{TaON}$ 上沉积金属 $\mathrm{Pt}$ 作为产氢助催化剂时, 以 $\mathrm{Fe}(\mathrm{CN})_{6}{ }^{4-}$ 为电子供体的光催化产氢半反应基 本没有产氢活性, 而当沉积氧化物 $\mathrm{PtCrO}_{x}$ 作为产氢助催化剂时, 产氢半反应活性可提高至 $35 \mu \mathrm{mol} \mathrm{h}{ }^{-1}$. 进一步研究发现, 这种产氢活性的差异主要是由于两种不同助催化剂对于 $\mathrm{Fe}(\mathrm{CN})_{6}{ }^{3-}$ 引起的氢气氧化逆反应的催化行为不同. 金属Pt表面对 于氢气具有吸附和活化作用, 光催化反应中产生的氢气和 $\mathrm{Fe}(\mathrm{CN})_{6}{ }^{3}$ 在 $\mathrm{Pt}-\mathrm{ZrO}_{2} / \mathrm{TaON}$ 催化作用下发生快速的氧化还原逆反 应; 而由于 $\mathrm{PtCrO}_{x}$ 表面对氢气的吸附和活化作用较弱, 上述氢气氧化的逆反应在 $\mathrm{PtCrO}_{x}-\mathrm{ZrO}_{2} / \mathrm{TaON}$ 存在时不发生. 此外, 在 产氢过程中, 光生电子虽然迁移到助催化剂 $\mathrm{PtCrO}_{x}$ 上, 但 $\mathrm{PtCrO}_{x}$ 中高氧化态的 $\mathrm{Pt}^{\mathrm{II}}$ 和 $\mathrm{Pt}^{\mathrm{IV}}$ 并未被还原, 因此使 $\mathrm{PtCrO}_{x}-\mathrm{ZrO}_{2} / \mathrm{TaON}$ 具有稳定的光催化产氢反应活性.

基于 $\mathrm{PtCrO}_{x}-\mathrm{ZrO}_{2} / \mathrm{TaON}$ 在 $\mathrm{Fe}(\mathrm{CN})_{6}{ }^{4}$ 作为电子供体时有效的产氢半反应, 我们以 $\mathrm{Fe}(\mathrm{CN})_{6}{ }^{3-4-4}$-作为电子递体, 将光系统 $\mathrm{II}$ 与 $\mathrm{PtCrO}_{x}-\mathrm{ZrO}_{2} / \mathrm{TaON}$ 耦合构建了生物-人工杂化 Z型全分解水体系, 通过调节 $\mathrm{Fe}(\mathrm{CN})_{6}{ }^{3-4}$-的初始浓度, 最终实现了杂化体系 的全分解水反应, 产氢和产氧活性分别为 $20 \mu \mathrm{mol} \mathrm{H} \mathrm{H}^{-1}$ 和 $10 \mu \mathrm{mol} \mathrm{O}_{2} \mathrm{~h}^{-1}$. 这为理解和抑制以 $\mathrm{Fe}(\mathrm{CN})_{6}{ }^{3-/ 4-}$ 作为电子递体的 光系统II-人工杂化Z型水分解体系中的逆反应提供了新的思路.

关键词: 水分解; 助催化剂; 逆反应; 氢气氧化; 光系统II

收稿日期: 2018-11-21. 接受日期: 2019-01-07. 出版日期: 2019-04-05.

*通讯联系人. 电话: (0411)84379070; 传真: (0411)84694447; 电子信箱: canli@dicp.ac.cn

基金来源: 中国科学院战略性先导科技专项(XDB17000000); 中国科学院前沿科学重点研究计划(QYZDY-SSW-JSC023); 国家自

然科学基金 (21603224, 31470339); 国家重点研发计划(2017YFA0503700).

本文的电子版全文由Elsevier出版社在ScienceDirect上出版(http://www.sciencedirect.com/science/journal/18722067). 